\title{
THE REPRESENTATION OF WOMEN IN LI YOUNG-LEE'S POEMS
}

\author{
Patricia Vania Septhine Yulia Asthereni
}

Magister Programme of English Language Studies (Kajian Bahasa Inggris), Sanata Dharma University, Jl. Affandi, Mrican, Caturtunggal, Depok, Sleman, DIY 55281, Indonesia

\section{A RTICLE INFO}

Keywords:

Partriarchal relation

Sexuality

Sexual objectification

Woman portrayal

Article History:

Received: $12 / 03 / 2020$

Accepted: $31 / 05 / 2020$

Available Online:

$31 / 05 / 2020$

\begin{abstract}
A B S T R A C T
Patriarchy has become the central attention of feminism because its practices expand to many different fields in society, such as politics, law, power relations between male and female and literary works, such as poems. Lee, as a poet with a lot of notable achievements, also internalises his patriarchal ideology through the women representation portrayed in "Persimmons", "Braiding", "Pillow", "Early in the Morning" and "This Room and Everything in It". This study analyses five of Lee's poems utilising close reading to discover the exercises of patriarchy to the female characters in Lee's poems. The points are proven by six structures of patriarchal system, which cover six aspects of social life namely mode of production; salaried employment; state; male violence; culture, and relationship in sexuality. Women's portrayal in Lee's poems specifically reveals patriarchal relations in sexuality. This study concludes that Lee's portrayal of women in his poems is indeed patriarchal by means of (1) characterising women as weak and passive; (2) male dominating as evident in sexual relationship and (3) making women as sex objects.
\end{abstract}

2442-305X / (C) 2020 The Author, this is open access article under the (CC-BY-NC) license (https://creativecommons.org/licenses/by-nc/4.0/), DOI: 10.19105/ojbs.v14i1.3137

\footnotetext{
* Corresponding Author:

Email address: patriciavania77@gmail.com (P. V. S. Y. Asthereni)
}

\section{A. Introduction}

$\mathrm{Li}$ Young Lee, as an award-winning poet raises various themes in his works. They vary from familial love and love in general, racial discrimination, daily experiences, and even the process of finding identity. These themes, however, are concealed in his works, making the interpreting process of his all poems more challenging to uncover them. His most notable works are The City in Which I Love You (1990) poetry book and The
Winged Seed: A Remembrance (1995), a memoir which takes shape of a prose poem autobiography.

Although many critics have claimed that his poems are central to Chinese culture, ignoring his identity as an American; his Rose (1986) and The City in Which I Love You (1990), according to Zhou, are more than about a certain culture. Those two specific works of him contain how the self-identity from exploring and inventing within self is 
gained through "experiences of disconnection, dispossession and alienation". ${ }^{1}$ Kolosov, similar to Zhou who compliments Lee, remarks that Lee's poetry in general, utilises love (erotic love to be specific) in order to reconstruct the sense of loss, agony, and hatred from his personal experiences in the past. ${ }^{2}$ A study by Yao examines "Persimmons" as the focus asserting it as the perfect way of "grafting" rather than simply cultural hybridisation as Lee attempts to integrate the elements of Chinese culture into the fundamental form of English poetry. ${ }^{3}$ Women issues, however, are not often the focus of the critics on Lee's poems.

This study, therefore, is to examine the representation of women which is very patriarchal as portrayed in Lee's poems. Because it analyses the literary works from a feminist point of view, it is a type of gender study, with the focus on feminist literary criticism specifically. As what Beauvoir asserts in Leitch, patriarchy establishes women as "immanence" who are naturally inactive (in social, political and cultural life) and men as "transcendence" who are always seeking for independence. ${ }^{4}$

\footnotetext{
${ }^{1}$ Zhou Xiaojing, "Inheritance and Invention in LiYoung Lee's Poetry," Multi-Ethnic Literature of the United States (MELUS) 21, no. 1 (March 1, 1996): 113-32, https://doi.org/10.2307/467810.

2 Jacqueline Kolosov, "Poetries of Transformation: Joy Harjo and Li-Young Lee," Studies in American Indian Literatures 15, no. 2 (2003): 39-57.

3 Steven Yao, "The Precision of Persimmons: Hybridity, Grafting and the Case of Li-young Lee," Lit: Literature Interpretation Theory 12, no. 1 (January 1, 2001): 1-23, https://doi.org/10.1080/10436920108580279.

${ }^{4}$ Vincent B. Leitch et al., "Simone de Beauvoir," in The Norton Anthology of Theory and Criticism:
}

The analysis of women representation in the poems deals with literary representation, social construction which includes establishing the identity of women and more in voicing the rights of women's sexuality. Analysing sexuality closely links to how male domination constrains all aspects in women's lives. It will be highlighting less on the Marxist and psychoanalytic field. It uses the close reading method. As Jockers believes via Smith, close reading relies on "careful observation" and "concentrated reading of the text" ${ }^{5}$

It will discuss only five among his many poems, namely "Persimmons" (1986), "Braiding" (1986), "Pillow" (2001), "Early in the Morning" (1986) and "This Room and Everything in It" (1990). "Persimmons" which is the linking item of the seemingly scattered memories of the narrator, recounts of the painful memory when he was discriminated by his teacher, the memorable memory when his parents know and miss their hometown (where persimmon originates) and the ironic moment when the narrator forgot his own mother tongue. ${ }^{6}$

The second poem's "Braiding" contains the word "braid" which become the prelude and postlude of how the narrator expresses his longing for his

Third Edition Norton Anthology (New York, London: W.W. Norton \& Company, 2018), 1212.

${ }^{5}$ Barbara Smith, "What Was 'Close Reading'?: A Century of Method in Literary Studies," The Minnesota Review 87 (January 1, 2016): 57-75, https://doi.org/10.1215/00265667-3630844.

6 Li Young Lee, "Persimmons," in Rose (Brockport, United States: BOA Editions Ltd, 1986), 17-19, https://www.poetryfoundation.org/poems/43011/per simmons. 
lover. Inevitably, the tone in this poem is very romantic as it depicts love. ${ }^{7}$

Next, "Pillow", with a very different tone compared to "Braiding", illustrates how the sleepless night of the narrator begins. Different from the two previous poems, in "Pillow", the word pillow itself is not mentioned, even once; but rather is implied in the first stanza. ${ }^{8}$

In "Early in the Morning", the warmth of family set in the morning is evidently portrayed. Without doubt, it delivers the same warmth to the readers as a very reminder of how morning starts. Again, as the poem evidently hints about morning, the word morning is not mentioned. ${ }^{9}$

The fifth poem, "This Room and Everything in It" passionately illustrates the narrator's love and yearning with the detailed description of the things that are in the room. ${ }^{10}$

The five poems are selected because they portray the representations of women which are patriarchal. This value of being patriarchal, certainly, could be derived from Lee's background as an Asian. Both of Lee's parents are Chinese.

\footnotetext{
$7 \mathrm{Li}$ Young Lee, "Braiding," in Rose (Brockport, United States: BOA Editions Ltd, 1986), 57, https://www.poemhunter.com/poem/braiding/.

8 Li Young Lee, "Pillow," in Book of My Nights (United States: BOA Editions Ltd, 2001), 1, https://www.poemhunter.com/best-poems/li-younglee/pillow/.

9 Li Young Lee, "Early in the Morning," in Rose (Brockport, United States: BOA Editions Ltd, 1986), 25 ,

https://www.poetryfoundation.org/poems/48803/earl $y$-in-the-morning.

${ }^{10}$ Li Young Lee, "This Room and Everything in It," in The City in Which I Love You (Rochester, New York: BOA Editions Ltd, 1990), 49, https://www.poetryfoundation.org/poems/43328/this -room-and-everything-in-it.
}

But, it is essential to also remind ourselves that patriarchy has its roots in Western society for long. Nevertheless, this study will, then, disregard the rich culture that Lee has gained throughout his experiences for staying in different places since he was born in Indonesia, traveled through Indochina and Southeast Asia before staying in Hong Kong and then the United States. ${ }^{11}$ Yet, to gain more elaborated interpretation of how Lee illustrates women in his poems, connecting his first-hand experiences on different cultures would mean little to his portrayal of women. It is because like what Mitchell argues in Butler's article that someone's patriarchal ideology is shaped far before he/ she can consciously be selective of it. ${ }^{12}$

Comparing this very work to Arianto's feminist study which uses Welter's indoctrination. ${ }^{13}$ This study used Walby's six structures of patriarchal society which are employment, household production, the state, violence, culture and sexuality. ${ }^{14}$

Mace, who similarly applies Walby's theory, focuses more on the sociological

\footnotetext{
${ }^{11}$ Xiaojing, "Inheritance and Invention in Li-Young Lee's Poetry."

12 Judith Butler, "Rethinking Sexual Difference and Kinship in Juliet Mitchell's Psychoanalysis and Feminism," Differences 25, no. 2 (2012): 1-19, https://doi.org/10.1215/10407391-1629794.

13 Tomi Arianto and Ambalegin, "Indoctrination against Women in The Lowland by Jhumpa Lahiri," OKARA: Jurnal Bahasa dan Sastra 12, no. 2 (November 2018): 153-66, https://doi.org/10.19105/ojbs.v12i2.1935.

14 Sylvia Walby, "Structuring Patriarchal Societies," in Sociology: Introductory Readings, by Antony Giddens and Philip W Sutton, 3rd ed. (Cambridge: Polity Press, 2010), 30-35.
} 
aspect of patriarchy and refuses to recognise that patriarchy has influenced the social relations of gender. ${ }^{15}$ Unlike Mace's study, this study will put more emphasis on how the representation of women in Lee's works is related to patriarchal relation in sexuality.

Adriana, both in Bahasa dan Gender: Antara Dominasi dan Subordinasi (Sebuah Kajian Sosiolinguistik) $^{16}$ and Representasi Kekuasaan dalam Ragam Sapaan Suami Istri di Sampang Madura (Sebuah Kajian Etnografi Berbahasa dalam Gender $^{17}$ may have the most similar aim to this study which is to uncover the concealed male domination upon gender relations. Her studies, though, are in the scope of linguistics and this study is in literature.

\section{B. Walby's Six Structures of Patriarchal System}

Walby, in Sociology: Introductory Readings, defines patriarchy to be "a system of social structures and practices in which men dominate, oppress and

\footnotetext{
15 Eric Macé, "From Patriarchy to Composite Gender Arrangements? Theorizing the Historicity of Social Relations of Gender," Social Politics: International Studies in Gender, State \& Society 25, no. 3 (September 1, 2018): 317-36, https://doi.org/10.1093/sp/jxy018.

16 Iswah Adriana, "Bahasa dan Gender: Antara Dominasi dan Subordinasi (Sebuah Kajian Sosiolinguistik)," OKARA: Jurnal Bahasa dan Sastra 6, no. 2 (November 2012), http://dx.doi.org/10.19105/ojbs.v6i2.425.

17 Iswah Adriana, "Representasi Kekuasaan dalam Ragam Sapaan Suami Istri di Sampang Madura (Sebuah Kajian Etnografi Berbahasa dalam Gender)," OKARA: Jurnal Bahasa dan Sastra 8, no. 2 (November 2014): 1-18, http://dx.doi.org/10.19105/ojbs.v8i2.461.
}

exploit women". ${ }^{18}$ In the patriarchy system, there are six structures which establish it. They are patriarchal mode of production, patriarchal relations in paid work, patriarchal state, male violence, patriarchal culture, and patriarchal relations in sexuality.

Patriarchal mode of production commonly occurs in marriage and household. In this mode, male appropriates female to undertake labour, in which female does not get rewarded except for her upkeep. Walby argues that it plays a significant role in inequality because the labour done by men and women is a principal form of discrimination between men and women. The discrimination then leads to other elements in social relations.

Patriarchal relations in paid work develop because men stop access to paid work and other areas against women. It ensures the employment isolation, as well as the low wages for women as an oblique consequence of the isolation.

Further, the state is another consequence of patriarchal system as it has the characteristic of patriarchy. It roots from the inadequate power that women have upon the political forces. State had relatively excluded women from its matters (how women were allowed to vote later than men and the low percentage of women constituting the parliament).

The next structure, Walby argues that male violence has social structural attributes, rather than psychological. The

${ }^{18}$ Walby, "Structuring Patriarchal Societies," 30. 
practices of male violence (including rape, domestic violence, flashing, sexual assault, as well as sexual harassment at the workplace) significantly constructs how women act because they fear of male violence.

Patriarchal culture, the fifth structure, is what Walby defines as "a set of institutions" which perceive women from the patriarchal perspective. ${ }^{19}$ It commonly involves discourses on femininity and masculinity which are incorporated into all systems of social life.

In the last structure, sexuality is a fundamental structure of patriarchy. Crenshaw uses MacKinnon's argument in reviewing whether it is true that sexuality for feminism is considered as the similar significance of what labour is for Marxism because of its essential and overpowering magnitude. ${ }^{20}$ Through sexuality, men justify their control by objectifying and dominating women. Sexuality (both heterosexuality and sexual practice), Walby asserts, has become more significant as the form of women's subordination.

Acknowledging the same point made by Walby, Dworkin in Edward's Erotics and Politics maintains that sexuality is perceived as the principal instrument for men to dominate women. ${ }^{21}$

\footnotetext{
${ }^{19}$ Walby, 31.

20 Kimberle W. Crenshaw, "Close Encounters of Three Kinds: On Teaching Dominance Feminism and Intersectionality," Tulsa Law Review 46, no. 1 (2013):

$151-90$ https://digitalcommons.law.utula.edu/tır/vol46/iss $1 / 1$ 3.

21 Tim Edwards, Erotics and Politics (New York: Routledge, 2012), 10 \& 35.
}

This leads them to cultivate their power over women in society. Rather than about how gender inequalities influence women's sexual activity, it is more on how sexuality which based on male domination constricts all aspects of women's lives. Further, Rossan mentions that the concept of women's sexuality as the men's ownership (or "property", both referring women as object) constructs laws and social conventions. ${ }^{22}$

\section{Women Portrayal in Patriarchal Relations in Sexuality}

\section{Male Domination and Female Sexuality}

"Persimmons" portrays the experience of Lee's discrimination with the use of persimmon word to link every different stanza in the poem. Within the poem, however, there are representations of the woman which Lee gains as inherent patriarchal.

Donna undresses, her stomach is white./ In the yard, dewy and shivering/ with crickets, we lie naked,/ face-up, face-down. ${ }^{23}$

The fragment of "Persimmons" poem quoted above (third stanza, first until the fourth line) illustrates how two persons, namely Donna and the anonymous narrator, are having sex in the yard. As it is known that Lee asserts erotic love in his works, this kind of verse is common and unsurprising. However, the

\footnotetext{
22 Sheila Rossan, Introducing Women's Studies: Feminist Theory and Practice, ed. Diane Richardson and Victoria Robinson, 2nd ed. (London: The Macmillan Press Ltd, 1996), 153-54.

${ }^{23}$ Lee, "Persimmons."
} 
representation of women concerning the issue I am about to address is what follows after the quoted lines "I part her legs,/remember to tell her/she is beautiful as the moon." 24

On the ninth line of the third stanza, it says "I part her legs." Male domination over female in a sexual relationship becomes evident here. Since in the first line of the stanza, Donna undresses herself, it can be implied that she is more than capable to part her own legs. Yet, Lee chooses to put "I" there instead of Donna herself, as the one who part her legs in a sexual intercourse. On the first hand, it can be seen as a romantic element which depicts how the two different persons become one. But, on the other hand, specifically perceiving it from Walby's claim; it is a form of male domination over women which is constructed within patriarchal system. The act of domination is justified through, what was once defended as natural, the sexual discourse.

In the poem, the sexual discourse even implies more than a justification, rather it is on what makes the narrator justifies his way of thinking to be able to dominate Donna through such act. The first and fifth stanza recounts the narrator's past involving his American teacher discriminating him through a persimmon. Hurt by his American teacher, the narrator is taking his revenge through sexual relationship. It is supported as well by the fact that Donna is an American girl (inferred from "her stomach is white").

24 Lee.
Donna then, has the same characteristic as the narrator's teacher who had once scarred him.

Thus, this kind of dominating women through sexual discourse is seen to be problematic for both men and women by some writers. Potts, Tiefer and Gavey in Gupta, for example, argue that it is as puzzling for men alike because they end up believing that their masculinity revolves around active inquiry of sexual activity. ${ }^{25}$ Their argument, withal, just proves that sexual discourse is not a natural activity. Rather, it is proven as a result of particular social construction, which is the structure of patriarchal system.

\section{Women as the Weak Party}

Moving on to the next poem, "Braiding", the first stanza contains the description of women according to patriarchy. Here are the very lines which demonstrate it.

We two sit on our bed, you/between my legs, your back to me, your head/slightly bowed, that I may brush and braid/your hair. My father/did this for my mother,/just as I do for you. One hand/holds the hem of you hair, the other/works the brush. Both hands climb/as the strokes grow/longer, until I use not only my wrists,/but my arms, then my shoulders, my whole body/rocking in a rower's rhythm, a lover's/even time, as the tangles are undone. ${ }^{26}$

The intimacy between a couple of lovers is demonstrated through the first stanza. Putting the narrator's lovers

\footnotetext{
25 Kristina Gupta, "Compulsory Sexuality: Evaluating an Emerging Concept," Signs 41, no. 1 (2015): 131-54, https://doi.org/10.1086/681774.

${ }^{26}$ Lee, "Braiding."
} 
between his legs to brush her hair may seem normal and very romantic at a glance. Yet, the concealed patriarchal ideology is shown once again. Lee chooses to place the woman in his poem below the man (between his legs), which is supposedly her lover. If it is not done because of his repressed thought as the dominant one, Lee can use better words to depict their positions on the bed, like "close to my body" or "that I can feel your warmth" instead of "between my legs".

And as if it is not derogating enough, the woman is once again illustrated as a weak and dependent being by having the man "brush and braid" her hair in the following stanza. One of us will have to imagine this.

You,/after your bath, crosslegged on the bed, sleepy, patient,/while I braid your hair. ${ }^{27}$

It may be perceived as a symbol of love, but instead of illustrating another situation to convey love; Lee chooses a simple act of brushing and braiding hair to portray it. This portrayal turns out to be effective in depicting the woman's dependence towards the narrator since the woman stays still (illustrated as "slightly bowed" and "crosslegged on the bed, sleep, patient") and the man is the one who does everything for his lover.

In the following lines, the identical scene of sexual discourse emerge once again. As the previous discussion, male domination occurs in the illustration. However, the passivity of the woman and the activeness of the man is enhanced in

27 Lee. details. It is like only the movements of the man is essential, while the woman's action is not described. His movements include "use not only my wrists, my arms, then my shoulders" and "my whole body rocking in a rower's rhythm". It demonstrates emphasis on the man, as the subject, and reduces the woman's sexuality into non-existent.

In relation to it, the very line of "My father did this for my mother, just as I do for you" is very allusive. As the narrator seems to imitate his parents' behaviour regarding sexuality, it exhibits that sexuality is socially constructed. My argument is supported by the argument of Herdt et al. in Alexander's "Discursive Studies: Bridging Sexuality and Literacy Studies". They declare that sexuality informs human of their identity and the cultural values that both can be shared and failed to be shared. ${ }^{28}$

Yet, I am questioning what else has the narrator adopt from them, if it is not patriarchy? As argued by Einspahr, patriarchy is systematic domination constituted of domination background which makes men feel superior to women. ${ }^{29}$ This domination background is the patriarchal relations in sexuality as described in the first stanza of "Braiding" poem, where the emphasis is grounded

\footnotetext{
28 Jonathan Alexander, 'Discursive Sexualities: Bridging Sexuality and Literacy Studies', in Litieracy, Sexuality, Pedagogy (Colorado: University Press of Colorado, 2008), 41. https://doi.org/10.2307/j.ctt4cgqkw.

29 Jennifer Einspahr, "Structural Domination and Structural Freedom: A Feminist Perspective," Feminist Review 94, no. 1 (March 1, 2020): 1-19, https://doi.org/10.1057/fr.2009.40.
} 
on the man and the woman is just an ornament.

On the third poem, "Pillow", the representation of the narrator's mother is letting go of the thread and the narrator's father is repairing the clock.

And night begins when my mother's fingers/let go of the thread/they've been tying and untying/to touch toward our fraying story's hem./Night is the shadow of my father's hands/setting the clock for resurrection. ${ }^{30}$

It presents a weak woman through the depiction of her unravelling the thread. It is contradictory to the depiction of the narrator's father which is the one in control ("setting the clock for resurrection"). The woman is giving up, while the man is never surrendering is what Lee implies here. To call this very stanza as a mere comparison is an understatement because the actions done by the characters outline what patriarchy system believes. That woman is weaker and more inferior than men, who is stronger and more capable in many aspects compared to women. Further, it is more about the division of domestic labour which is very patriarchal. Women are more into knitting, if the act of "tying and untying" thread refers to knitting and men's labours are rather mechanical involving machinery.

\section{Sexual Objectification towards Women}

The following poem, "Early in the Morning" contains the very portrayal which involves both sexual objectification by the

${ }^{30}$ Lee, "Pillow." man and self-objectification by the woman.

Bartky, in Szymanski et al., asserts that sexual objectification is a phenomenon which happens when woman's body or body parts are perceived to be dissociated and separated from her as a human being. She is then be viewed mainly as a physical object to fulfil male sexual desire. ${ }^{31}$ Further, Fredrickson and Roberts in Vaes et al. assert that in sexual objectification, one side focuses on the other's usefulness as "a product of consumption" and the other side of sexual objectification refers to herself in different forms of dehumanization. ${ }^{32}$

Fredrickson and Roberts in Puvia and Vaes define self-objectification as how women adopt an outsider's perspective to see their physical appearance and to treat themselves as objects for others to appraise and acknowledge them. ${ }^{33}$

My mother combs,/pulls her hair back tight, rolls it/around two fingers, pins it/in a bun to the back of her head./For

${ }^{31}$ Dawn M. Szymanski, Lauren B. Moffitt, and Erika R. Carr, "Sexual Objectification of Women: Advances to Theory and Research," The Counseling Psychologist 39, no. 1 (2011): 6-38, https://doi.org/10.1177/0011000010378402.

32 Jeroen Vaes, Paola Paladino, and Elisa Puvia, "Are Sexualized Women Complete Human Beings? Why Men and Women Dehumanize Sexually Objectified Women," European Journal of Social Phychology, Published Online in Wiley Online Library, no. 41 (2011): 774-85, https://doi.org/10.1002/ejsp.824.

33 Elisa Puvia and Jeroen Vaes, "Being a Body: Women's Appearance Related Self-Views and Their Dehumanization of Sexually Objectified Female Targets," Sex Roles 68 (December 29, 2012): 484-495, https://doi.org/10.1007/s11199012-0255-y. 
half a hundred years she has done this./My father likes to see it like this./He says it is kempt. ${ }^{34}$

The objectification of the mother as the woman in the poem, evidently shows in how the hair becomes the theme of the third stanza. Instead of highlighting more on other aspects of the mother as a person (how she treats her family or the best non-physical quality of her), the hair is taken apart from her as an object which has certain uses (instrumental). The very reason of it is to fulfil male's desire, although it is not certain yet that it is a sexual one, since it turns out that the father likes to see that kind of hairstyle that the mother wears.

The very same line of "My father likes to see it like this" also indicates the mother's self-objectification. Certainly, the voice of the woman is silenced in the poem (only the father speaks and the mother acts) that the reason why the mother likes to roll her hair in a bun is unexplored. But, putting the father's appraisal after, suggests that the mother does her hair like that for fifty years because her man loves it. Because one certain man likes her hairstyle, she cares about her hair appearance, which is very physical.

But I know/it is because of the way/my mother's hair falls/when he pulls the pins out./Easily, like the curtains/when they untie them in the evening. ${ }^{35}$

The sexual objectification of the mother becomes evident in the last stanza of the poem. On top of dissociating her hair apart from her as a person, the father's liking of her hairstyle is driven by sexual drive of untying the hair in the evening when they are having sexual discourse. Among the many reasons for liking someone's hairstyle, Lee links it to another bed scene yet. Indicating to another hint of patriarchal ideology of him, he considers such daily events happening in his life and the reasons for it as perfectly normal and common. This kind of perception is influenced by his surroundings a lot and I dare say that it is the patriarchy which shapes his values to be filled with the justification of male domination.

The sexual objectification of women becomes more apparent in the last poem entitled "This Room and Everything in It". The poem describes a room in which the narrator spent his time with his lover. The longing and romantic tone is hinted, but Lee's portrayal of the woman's body parts emerges to be the focus of the poem.

Your sunken belly/is the daily cup of milk I drank/as a boy before morning prayer./God, your body is milk... ${ }^{36}$

The two quotes utilise metaphor to allege comparison between the woman's "sunken belly" and "body" and "milk". As narrated, the body parts are disassociated from the woman. It makes the woman be seen as an incomplete human being, but rather to be perceived as an instrument to fulfil the male's sexual drive (sexual objectification). The other sexual objectification of women can be found in

${ }^{36}$ Lee, "This Room and Everything in It."

\footnotetext{
${ }^{34}$ Lee, "Early in the Morning."

${ }^{35}$ Lee.
}

OKARA: Jurnal Bahasa dan Sastra, Vol. 14, No. 1, May 2020 
the following lines; " $/ . . . .$. your hair is time, your thighs are song..."37

Lee compares parts of a woman, animate as something inanimate, milk, contrasted to his analogy of the narrator into a boy; both the narrator and a boy are animate. In other words, the woman is the object, inanimate thing in comparison to the man as a human being, implying him as the subject superior to the object.

On top of the disconnected analogy of the woman as an object and the man as the subject, "milk" here is implied to be the milky fluid that women produce during sexual arousal. The lines, then, serve as another justification for men to dominate women through sexual discourse. The male domination is once again portrayed as the man is the one who actively does something. $\mathrm{He}$ is also the one on control as he "drinks" the "milk". Domination of men over women still outweighs Lee's illustration of how men and women communicate, significantly during sexual relationships.

In the following line, sexual objectification of women still ensues this poem; "/your cries are song, my body's not me..."38 It can be implied that it is sexual through "your cries" which the man considers as "my song". He seems to enjoy the cries of the woman because it is he who makes the woman cries. Once again, how sexual intercourse is the main instrument for men's domination over women is proven through this line.
The notion that men have rights over women, or to some extent, and even possess over them is developed through the system which allows that kind of thinking to preserve. This system is what is insisted on as the patriarchal system. Departing from domination which occurs during sexual discourse (again, this very discourse is also construction based), it constructs other aspects of human life such as politics, economics, and law.

\section{Conclusion}

Using Walby's six structures of patriarchy, the study finds out that women representation as shown in Lee's poems is indeed patriarchal. Firstly, the illustrations of women in the five poems do not always fit all six structures that one poem consists of more structures than the other. Secondly, the findings also discover that Lee's five poems; "Persimmons", "Braiding", "Pillow", "Early in the Morning" and "This Room and Everything in It"; portray women as to how patriarchy system perceives them in a sexual relationship.

This patriarchal portrayal is achieved through women's characterisation as weak and passive in "Persimmons", "Braiding", "Pillow" and "This Room and Everything in It"; women's subordination during sexual relationship in "Persimmons" and "Braiding"; and also sexual objectification of women in "Early in the Morning" and "This Room and Everything in It".

\footnotetext{
37 Lee.

38 Lee.
} 


\section{References}

Adriana, Iswah. "Bahasa dan Gender: antara Dominasi dan Subordinasi (Sebuah Kajian Sosiolinguistik)." OKARA: Jurnal Bahasa dan Sastra 6, no. 2 (2012). http://dx.doi.org/10.19105/ojbs.v6i2. 425.

. "Representasi Kekuasaan dalam Ragam Sapaan Suami Istri di Sampang Madura (Sebuah Kajian Etnografi Berbahasa dalam Gender)." OKARA: Jurnal Bahasa dan Sastra 8, no. 2 (2014): 1-18. http://dx.doi.org/10.19105/ojbs.v8i2. 461.

Alexander, Jonathan. "Discursive Sexualities: Bridging Sexuality and Literacy Studies." In Literacy, Sexuality, Pedagogy. Colorado: University Press of Colorado, 2008. 10.2307/j.ctt4cgqkw.

Arianto, Tomi, and Ambalegin. "Indoctrination against Women in The Lowland by Jhumpa Lahiri." OKARA: Jurnal Bahasa dan Sastra 12, no. 2 (November 2018): 153-66. https://doi.org/10.19105/ojbs.v12i2.1 935.

Butler, Judith. "Rethinking Sexual Difference and Kinship in Juliet Mitchell's Psychoanalysis and Feminism." Differences 25, no. 2 (2012): $1-19$ https://doi.org/10.1215/104073911629794.

Crenshaw, Kimberle W. "Close Encounters of Three Kinds: On Teaching Dominance Feminism and Intersectionality." Tulsa Law Review 46, no. 1 (2013): 151-90. https://digitalcommons.law.utula.edu /ttr/vol46/iss1/13.

Edwards, Tim. Erotics and Politics. New York: Routledge, 2012.

Einspahr, Jennifer. "Structural Domination and Structural Freedom: A Feminist Perspective." Feminist Review 94, no. 1 (March 1, 2020): 1-19. https://doi.org/10.1057/fr.2009.40.

Gupta, Kristina. "Compulsory Sexuality: Evaluating an Emerging Concept." Signs 41, no. 1 (2015): 131-54. https://doi.org/10.1086/681774.

Kolosov, Jacqueline. "Poetries of Transformation: Joy Harjo and LiYoung Lee." Studies in American Indian Literatures 15, no. 2 (2003): 39-57.

Lee, Li Young. "Braiding." In Rose, 57. Brockport, United States: BOA Editions Ltd, 1986. https://www.poemhunter.com/poem/ braiding/.

. "Early in the Morning." In Rose, 25. Brockport, United States: BOA Editions Ltd, 1986. https://www.poetryfoundation.org/po ems/48803/early-in-the-morning.

"Persimmons." In Rose, 17-19. Brockport, United States: BOA Editions Ltd, 1986. https://www.poetryfoundation.org/po ems/43011/persimmons.

. "Pillow." In Book of My Nights, 1. United States: BOA Editions Ltd, 2001.

https://www.poemhunter.com/bestpoems/li-young-lee/pillow/.

. "This Room and Everything in It." In The City in Which I Love You, 49. Rochester, New York: BOA Editions Ltd, 1990. https://www.poetryfoundation.org/po ems/43328/this-room-andeverything-in-it.

Leitch, Vincent B., William E. Cain, Laurie A. Finke, John McGowan, T. Denean Sharpley-Whiting, and Jeffrey J. Williams. "Simone de Beauvoir." In The Norton Anthology of Theory and Criticism: Third Edition Norton Anthology, 1211-14. New York, London: W.W. Norton \& Company, 2018.

Macé, Eric. "From Patriarchy to Composite Gender Arrangements? 
Theorizing the Historicity of Social Relations of Gender." Social Politics: International Studies in Gender, State \& Society 25, no. 3 (September 1, 2018): 317-36. https://doi.org/10.1093/sp/jxy018.

Puvia, Elisa, and Jeroen Vaes. "Being a Body: Women's Appearance Related Self-Views and Their Dehumanization of Sexually Objectified Female Targets." Sex Roles 68 (December 29, 2012): 484-495.

https://doi.org/10.1007/s11199-0120255-y.

Rossan, Sheila. Introducing Women's Studies: Feminist Theory and Practice. Edited by Diane Richardson and Victoria Robinson. 2nd ed. London: The Macmillan Press Ltd, 1996.

Smith, Barbara. "What Was 'Close Reading'?: A Century of Method in Literary Studies." The Minnesota Review 87 (January 1, 2016): 5775.

https://doi.org/10.1215/002656673630844.

Szymanski, Dawn M., Lauren B. Moffitt, and Erika R. Carr. "Sexual Objectification of Women: Advances to Theory and Research." The Counseling Psychologist 39, no. 1 (2011): 6-38. https://doi.org/10.1177/0011000010 378402.

Vaes, Jeroen, Paola Paladino, and Elisa Puvia. "Are Sexualized Women Complete Human Beings? Why Men and Women Dehumanize Sexually Objectified Women." European Journal of Social Psychology, Published Online in Wiley Online Library, no. 41 (2011): 774-85. https://doi.org/10.1002/ejsp.824.

Walby, Sylvia. "Structuring Patriarchal Societies." In Sociology: Introductory Readings, by Antony Giddens and Philip W Sutton, 3rd ed. Cambridge: Polity Press, 2010.
Xiaojing, Zhou. "Inheritance and Invention in Li-Young Lee's Poetry." MultiEthnic Literature of the United States (MELUS) 21, no. 1 (March 1, 1996): 113-32. https://doi.org/10.2307/467810.

Yao, Steven. "The Precision of Persimmons: Hybridity, Grafting and the Case of Li-young Lee." Lit: Literature Interpretation Theory 12, no. 1 (January 1, 2001): 1-23. https://doi.org/10.1080/1043692010 8580279. 